\title{
Determinants of Foreign Direct Investment and its Statistical Analysis
}

\author{
Nadeem Ahmed Shaikh \\ Dr. Ishaque Ahmed Ansari
}

\begin{abstract}
Foreign direct investment (FDI) is investment that serves the business interests of the capitalist in an enterprise, which is in a different economy distinct from the investor's country of origin. FDI plays an unusual and growing part in world market. It can provide new markets and marketing channels, cheaper production facilities, access to new technology, products, dexterity and financing for businesses. For a host country or the foreign business which receives the investment, it can provide a source of state-of-theart technology, capital, processes, products, organizational technologies and management skills, and as such can provide a strong drive to economic development. In recent years, given rapid development and change in global investment approach, the definition has been broadened to include the acquisition of a lasting management interest in a company outside the investing company's home country. It may take many forms, such as a direct acquisition of a foreign firm, construction of a facility, or investment in a joint venture or strategic alliance with a local business with attendant input of technology, licensing of intellectual property. It produces a positive result on economic growth in host countries. Ironically, the presence of foreign companies in Pakistan predates the beginning of the country itself. Foreign investment and trade from the world, policy makers should consider the factors that attract multinational organizations to bring more investment in the economy and channelizing the investment in production sector to increase the turnover and employment. Inflows of investment in agriculture and textile sectors will increase the efficiency of these sectors and will resolve the food crises and employment issues in the economy.
\end{abstract}

Keywords: FDI, exchange rate, openness, inflation, portfolio investment, economic growth, liberalization.

\section{Introduction}

\subsection{Background of the Study}

Foreign direct investment (FDI) is that investment that serves the business interests of the capitalist in an enterprise, which is in a different economy distinct from the investor's country of origin. FDI plays an unusual and growing part in world market. In this study the main determinants of FDI will be analyzed through statistical inferences

\footnotetext{
Nadeem Ahmed Shaikh is working as Assistant Vice President in IT Audit \& Compliance Wing of National Bank of Pakistan, Karachi, nadeemnas@nbp.com.pk

Dr. Ishaque Ahmed Ansari is Senior Joint Director, S\&DW Department, State Bank of Pakistan, Karachi, Ishaque.ahmed@sbp.org.pk
}

Journal of Independent Studies and Research - MSSE

Volume 9

Number 2

July 2011 63 
and finally give the relationship between the FDI which as a dependent variable and other determinants as independents variables. On the basis of an economic model which would be evaluated through statistical tools. Many years ago, FDI flows were grown at a faster pace as compared to the world trade. Global sales of foreign affiliates of multinationals have exceeded exports (UNCTAD 1997). Part of this expansion in FDI can be attributed to the policy shift of many governments toward attracting FDI or restricting it at minimum. From 1991 to 1998 , some countries started to take a proactive approach toward attracting FDI by increasing the number of such countries.

\subsection{Problem Statement}

Objective of this study is to identify major influential determinants of FDI to assist policymakers in planning policies to attract FDI flows in Pakistan's economy. This is a macro level study focusing determinants at country level rather than micro level of industries or firms.

\subsection{Objectives of the Study}

The objective of the study is to explore the determinants of FDI inflows in Pakistan from 1975 to 2008. The crux of this study is to identify the main factors which may influence FDI, and how these may assist the policy-makers in order to attract private investment and to make investors' decision making processes more realistic? The study focuses on capturing the components of institutional development that account for receivables of a country, on the basis of increase or decrease in FDI. While analyzing the relationship between FDI inflows and FDI Fitness, this study concentrates on any host country determinants instead of industry/ firm determinants. The reason being is that factors of either of them are less important when host country factors are not in favor of FDI. The focus on institutional FDI Fitness as a determinant of FDI is intended to provide policy-makers, practitioners, scholars, and investors with a framework for examining the relationship between FDI Fitness Institutions and FDI. A sound understanding can be developed in each other's interests and constraints and such improved understanding will form better communication and cooperation in formation of institutional structures for FDI policies and procedures in consistent with national development targets.

\subsection{Research Methodology}

\subsubsection{Economic Model}

The model equation is given below.

$$
\mathrm{FDI}=\beta_{0}+\beta_{1} \mathrm{INF}+\beta_{2} \mathrm{OP}+\beta_{3} \mathrm{ER}
$$

In the model acronym FDI (FDI) is the dependent variable, whereas INF is used for Inflation, OP for openness, and ER for exchange rate which is independent variable. 


\subsection{Literature Review}

Recent studies propose that FDI has positive impact on economic growth through the process of technological transmission. The literature further emphasizes that the development of host country with its domestic financial system is an important prerequisite for FDI to positively contribute in the economic growth. The role of foreign economic support in economic growth and expansion remains contentious in economic literature. Some studies as per research have proved its affirmative impact on the economic development through empirical analysis, while others showed its negative impact as well. An empirical study of Chenery et al. (1966) concluded from Least Develop Countries (LDCs) that foreign investment has a positive effect on the economic development. The role of foreign aid varies from country to country. Ever since independence, Pakistan has relied on foreign aid to support its development programs and the aid still has a larger proportion in the foreign capital inflows to Pakistan. In Pakistan, several economists have tried to observe the role of foreign investment and aid in economic progress of Pakistan.

As Shabbir et al. (1992) and Khan et al.(1993) have concluded that aid has accelerated the rate of growth of GDP. One of the studies of Aslam (1987) observed that the public $\mathrm{FCl}$ did not impact the domestic investment radically, while the private $\mathrm{FCl}$ covered the gap between domestic saving and investment. Mahmood (1997) found that country may caught in a sever debt problems due to macroeconomic mismanagement, miss utilization of aid and inappropriate policies. Khan et al.(1993) concluded that foreign aid has played an extremely vital part in pressurizing the speed of growth, especially investments and imports have to a great level depended on the amount of foreign aid. Nevertheless on the one hand, this dependence on foreign aid has led to the emergence of increasing debt burden.

Recent studies show the impact of particular policy variables for FDI in the host countries. Such policies may include variables like openness of trade, tariffs, taxes and exchange rate. Gastanaga et al.(1998) and Asiedu (2002) has focused on policy restructuring in the developing countries in the form of determinants of FDI inflows. They have further analyzed that the corporate tax rates and degree of openness are the major determinants of FDI. Inflation directly affects the level of FDI. Actually this is that inflation when under control attracts more FDI in the host country or in any region. In addition, a low inflation rate highlight the investors that the monetary policy is being handled as per the defined parameters and the real returns from investing such countries would meet the investors' expectations (Agim Kukeli, 2007).

\subsection{An Overview of Foreign Direct Investment}

Direct investment is the type of international investment that reflects the aim of an occupant entity in one economy obtaining a lasting interest in a venture resident in another country. The lasting interest implies the existence of a long-term relationship between the direct investor and the enterprise and a significant degree of influence by the investor on the management of the enterprise. Direct investment includes not only the opening transaction beginning the relationship between the enterprise and the investor but also all succeeding transactions between them and among allied ventures. 


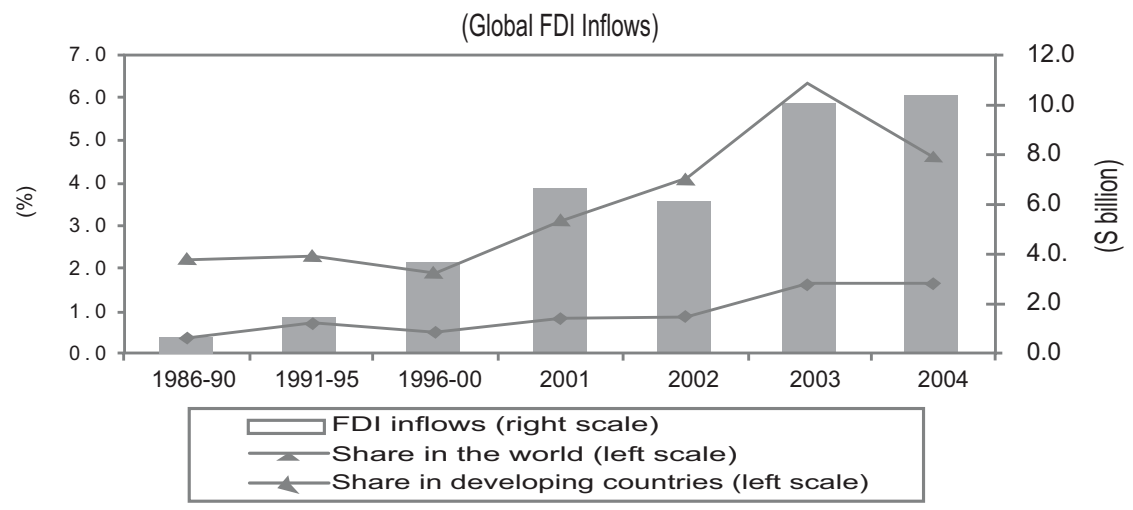

FDI has a major role to play in the economic growth of the host country. Over the years, FDI has facilitated the economies of the host countries to obtain a launching pad from where they may make further enhancements. This trend has marked itself in the last twenty years. Any form of FDI forces in a lot of capital knowledge and technological resources into the economy of a country. This helps in taking the particular host economy ahead. The fact that the foreign direct investors have been able to play an important role with respect to the economic development of the recipient countries.

\subsection{Foreign Direct Investment in South Asia}

When the foreign direct investment is reviewed in South Asia then the economic picture appears to come in the shape where it is analyzed that the Thailand was facing currency crisis in July 1997 and which has affected the other countries, especially Republic of Korea (Korea), Indonesia, and Malaysia, which restored the worth of prudential management of foreign capital flows in these developing countries where we find that the domestic financial markets are not yet completely developed. Such crises pose many challenges to the developing countries, containing that how best to manage financial institutions, how to proficiently administer the foreign exchange systems/reserves, and how to efficiently and effectively manage and control the foreign debts and investments. If we consider foreign resource mobilization from one point of view, it is observed that such crisis highlights the essential need to reconsider the best possible combination of foreign capital, i.e., portfolio investment, commercial loans, public loans of proper composition with confessional rate, and FDI.

Asian crisis has been triggered by volatile movements of portfolio investment, which was reinforced by alarming withdrawals of short-term commercial debts. It has been analyzed that there is no relationship with to FDI because of high steadiness. It depicts the magnitude of FDI in the Developing Member Countries (DMCs), mainly the group of least developed DMCs where domestic financial markets may crash and which may also create liquidity problems. Under such Pakistan comes in that group. In our country we may see that we have small financial market for foreign exchange whereas the debt position is unstable. During the last few years of 90s decade, foreign exchange reserves in Pakistan were below $\$ 1.3$ billion, which represent to only 4-5 weeks of imports of goods and services. In early 90 s, a decline has been noticed in short-term debt increased 
from $12 \%$ to $20 \%$. Such developments may increase the need for attracting FDI into Pakistan for getting better economic position.

\begin{tabular}{|c|c|c|c|c|c|c|c|c|c|c|}
\hline \multicolumn{7}{|c|}{ Table 1: FDI Inflows into Selected Countries (1995-2004) } & \multicolumn{4}{|c|}{ (Billions of US\$) } \\
\hline $\begin{array}{l}\text { Host Region/ } \\
\text { Economy }\end{array}$ & $\begin{array}{l}\text { 1990-1995 } \\
\text { (annual } \\
\text { avg.) }\end{array}$ & 1996 & 1997 & 1998 & 1999 & 2000 & 2001 & 2002 & 2003 & 2004 \\
\hline $\begin{array}{l}\text { World } \\
\text { Developed }\end{array}$ & 225.32 & 386.14 & 478.08 & 694.45 & 1088.26 & 1491.93 & 735.15 & 716.19 & 632.59 & 648.15 \\
\hline $\begin{array}{l}\text { economies } \\
\text { Developing }\end{array}$ & 145.01 & 219.90 & 267.947 & 484.23 & 837.76 & 1227.47 & 503.14 & 547.78 & 442.16 & 380.22 \\
\hline Counts. & 59.6 & 152.5 & 187.4 & 188.4 & 222.0 & 240.2 & 225.0 & 155.5 & 166.3 & 233.2 \\
\hline Asia & 47.32 & 93.33 & 105.82 & 96.10 & 102.77 & 133.70 & 102.066 & 92.0 & 101.28 & 147.54 \\
\hline Southeast & & & & & & & & & & \\
\hline Asia & 34.57 & 66.5 & 72.2 & 63.55 & 66 & 57.3 & 59.45 & 65.68 & 71.39 & 90.8 \\
\hline South Asia & 1.79 & 17.54 & 6.04 & 5.2 & 4.53 & 5.57 & 4.65 & 4.5 & 5.3 & 7.0 \\
\hline India & 0.7 & 2.5 & 3.6 & 2.6 & 2.1 & 2.3 & 3.4 & 3.4 & 4.2 & 5.3 \\
\hline Bangladesh & 0.6 & 14 & 1.3 & 1.9 & 1.7 & 2.8 & 0.7 & 0.52 & 0.26 & 0.46 \\
\hline Sri Lanka & 0.11 & 0.13 & 0.43 & 0.20 & 0.20 & 0.17 & 0.17 & 0.19 & 0.22 & 0.23 \\
\hline Pakistan & 0.38 & 0.91 & 0.71 & 0.50 & 0.53 & 0.30 & 0.38 & 0.82 & 0.53 & 0.95 \\
\hline PRC & 19.3 & 40.1 & 44.2 & 43.7 & 40.3 & 40.7 & 46.8 & 52.7 & 53.5 & 60.6 \\
\hline Republic of & & & & & & & & & & \\
\hline Korea & 0.97 & 2.3 & 2.8 & 5.4 & 9.3 & 9.2 & 3.1 & 2.9 & 3.7 & 7.6 \\
\hline Malaysia & 4.6 & 7.2 & 6.3 & 2.7 & 3.8 & 3.7 & 0.55 & 3.2 & 2.4 & 4.6 \\
\hline Singapore & 5.7 & 8.6 & 10.7 & 6.3 & 11.8 & 5.4 & 8.6 & 5.8 & 9.3 & 16.0 \\
\hline Indonesia & 2.1 & 6.1 & 4.6 & 0.35 & -2.7 & -4.5 & -3.3 & 0.14 & 0.59 & 1.0 \\
\hline Thailand & 1.9 & 2.2 & 3.6 & 5.1 & 3.5 & 2.8 & 3.7 & 0.94 & 1.9 & 1.0 \\
\hline Argentina & 3.5 & 6.9 & 9.1 & 6.8 & 24.1 & 11.1 & 3.1 & 2.1 & 1.8 & 4.2 \\
\hline Brazil & 20.0 & 10.7 & 18.9 & 28.8 & 28.5 & 32.7 & 22.4 & 16.5 & 10.1 & 18.1 \\
\hline
\end{tabular}

Source: World Investment Reports, Various Issues

\section{South Asias' Share in world FDI}

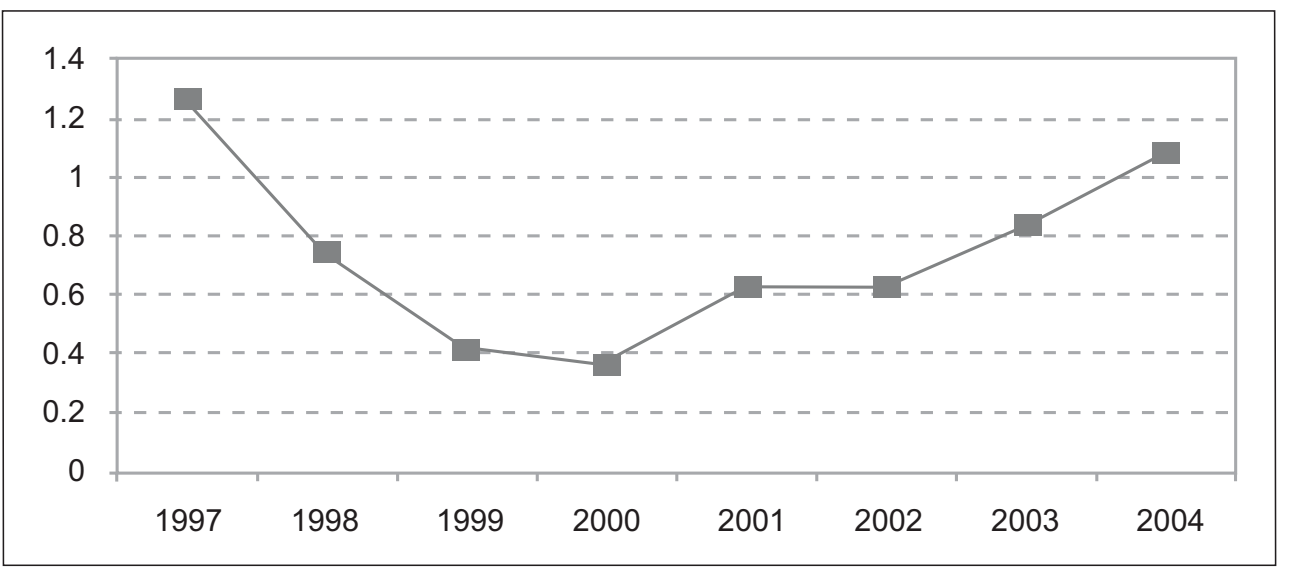

Source: World Investment Reports, Various Issues 


\section{Investment Policies of Pakistan}

The main theme of the policy consists of the following points:

- $\quad$ Fields for Foreign Direct Investment

- $\quad$ Approval Of Foreign Direct Investment

- $\quad$ Repatriation Facilities

- $\quad$ Remittances by Foreign Employees

- $\quad$ Equal Treatment

- $\quad$ Freedom to Bring, Holds, Sell And Take Out Foreign Currency

- Immunities to Foreign Currency Accounts

- $\quad$ Protection of Fiscal Incentives for Setting-up of Industries

- $\quad$ Protection of Transfer of Ownership to Private Sector.

- $\quad$ Protection of Foreign and Pakistan Investment

- $\quad$ Secrecy of Banking Transaction

- Protection of Financial Obligation.

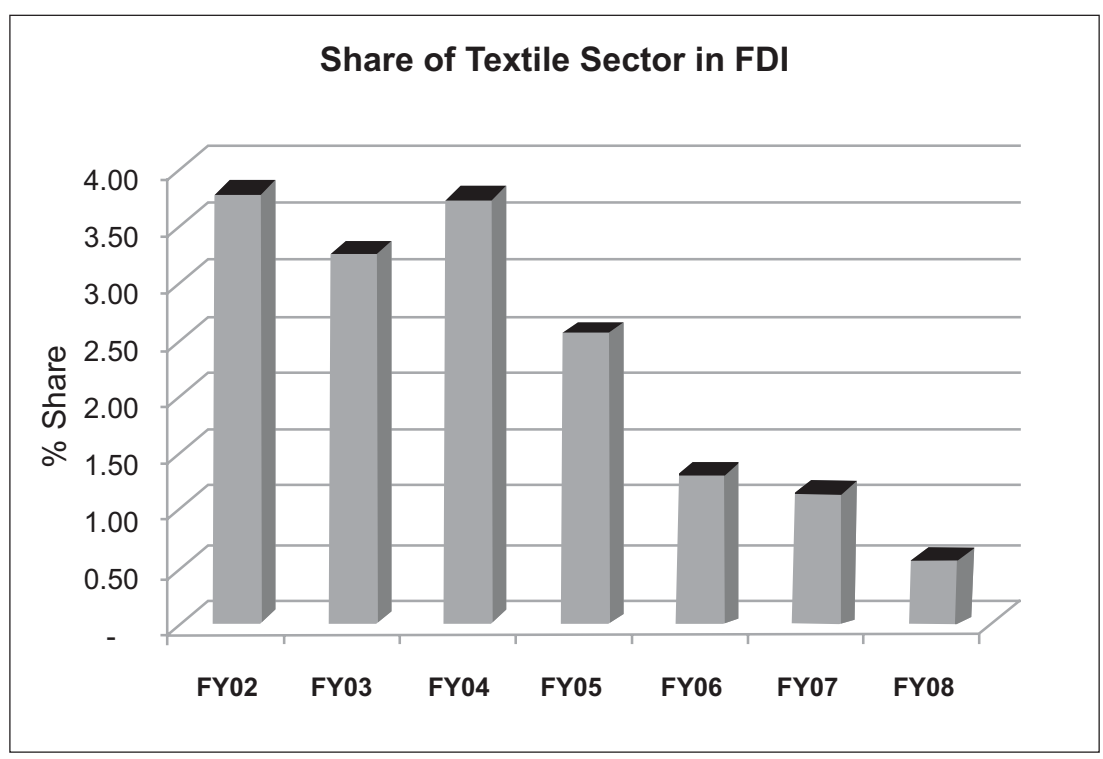

Source: State Bank of Pakistan 
Investment Policies

Attractive Ivestment Package

\begin{tabular}{|c|c|c|c|c|}
\hline \multirow[b]{2}{*}{ Policy Parameters } & \multirow[b]{2}{*}{ Manufacturing Sector } & \multicolumn{3}{|c|}{ Non - Manufacturing Sectors } \\
\hline & & Agriculture & $\begin{array}{l}\text { Infrastructure } \\
\qquad \& \text { Social }\end{array}$ & $\begin{array}{c}\text { Services } \\
\text { including IT \& } \\
\text { Telecom Servies }\end{array}$ \\
\hline Govt. Permission & $\begin{array}{l}\text { Not required except for } \\
\text { specified industries }^{*}\end{array}$ & \multicolumn{3}{|c|}{$\begin{array}{l}\text { Not required except for specified licenses from } \\
\text { concerned agencies. }\end{array}$} \\
\hline $\begin{array}{l}\text { Remittance of } \\
\text { capital, profits, } \\
\text { dividends, etc. }\end{array}$ & Allowed & \multicolumn{3}{|c|}{ Allowed } \\
\hline $\begin{array}{l}\text { Upper Limit of } \\
\text { of foreign equity } \\
\text { allowed }\end{array}$ & $100 \%$ & $100 \%$ & $100 \%$ & $100 \%$ \\
\hline $\begin{array}{l}\text { Minimum } \\
\text { Investment } \\
\text { Amoubt (M \$) }\end{array}$ & No & 0.3 & 0.3 & 0.15 \\
\hline $\begin{array}{l}\text { Customs duty on } \\
\text { import of PME }\end{array}$ & $5 \%$ & $0 \%$ & $5 \%$ & $0-5 \%$ \\
\hline $\begin{array}{c}\text { Tax relief (IDA, \% } \\
\text { of PME cost) }\end{array}$ & $50 \%$ & \multicolumn{3}{|c|}{$50 \%$} \\
\hline $\begin{array}{c}\text { Royalty \& } \\
\text { Technical Fee }\end{array}$ & $\begin{array}{c}\text { No restriction for } \\
\text { payment of royalty \& } \\
\text { technical fee. }\end{array}$ & \multicolumn{3}{|c|}{$\begin{array}{l}\text { Allowed as per guidelines-Initial lump-sum up to } \\
\$ 100,000 \text { _ Max. Rate } 5 \% \text { of net sales - Initial } \\
\text { period } 5 \text { years }\end{array}$} \\
\hline
\end{tabular}

*Specified Industries:

- Arms and ammunitions

PME= Plant, Machinery and

- High Explosives.

Equipment

- Radioactive substances

IDA= Initial Depreciation Allowance

- Security Printing, Currency and Mint.

No new unit for the manufacturing of alcohol, except, Industrial alcohol

Source: Board of Investment 


\section{Foreign Investment in Pakistan}

As we are aware that there are mainly two types of foreign private investments:

- $\quad$ Portfolio Investment

- $\quad$ Direct Investment

\subsection{Portfolio Investment}

"Portfolio investment implies holding by non-resident of less than $10 \%$ share in equity securities, investment in debt securities (in the form of bonds and notes) and investment in money market instruments of local company."

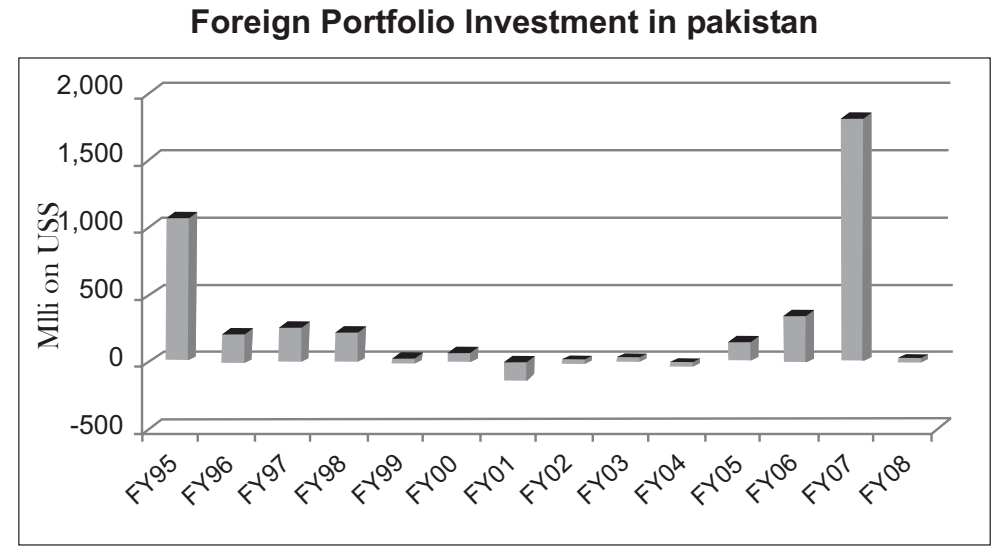

Source: State bank of pakistan

\subsection{Direct Investment}

"It is defined as an organization from one country making a physical investment into building a factory in another country. It is the establishment of a venture by a foreigner."

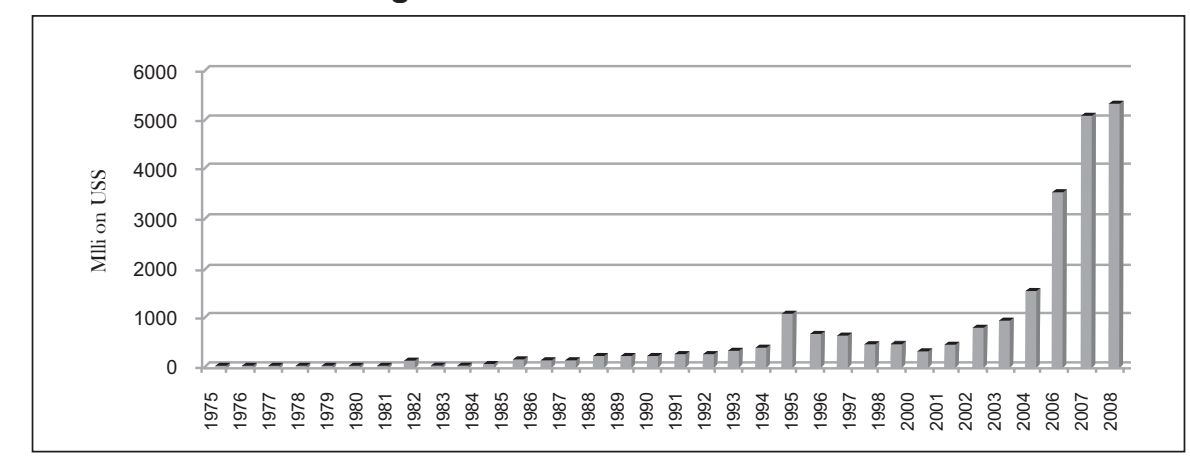

Source: State bank of pakistan 
Foreign Investment inflows in Pakistan (Million \$)

\begin{tabular}{|c|c|c|c|c|c|c|}
\hline \multirow{3}{*}{ Year } & \multirow{3}{*}{$\begin{array}{l}\text { Greenfield } \\
\text { Investment }\end{array}$} & \multirow{3}{*}{$\begin{array}{c}\text { Privatization } \\
\text { Proceeds }\end{array}$} & \multirow{3}{*}{$\begin{array}{l}\text { Total } \\
\text { FDI }\end{array}$} & Private & Public & Total \\
\hline & & & & Portfolio & Portfolio & Foreign \\
\hline & & & & Investment & Investment & Investment \\
\hline 2001-02 & 357 & 128 & 485 & -10 & -483 & -8.4 \\
\hline $2002-03$ & 622 & 176 & 798 & 22 & -261 & 559.1 \\
\hline 2003-04 & 750 & 199 & 949 & -28 & 339 & $1,260.70$ \\
\hline 2004-05 & 1,161 & 363 & $1,524.00$ & 153 & 458 & $2,134.60$ \\
\hline $2005-06$ & 1,981 & 1,540 & $3,521.00$ & 351 & 613 & $4,485.00$ \\
\hline 2006-07 & $4,873.20$ & 266 & $5,139.60$ & 1,820 & $1,468.30$ & $8,428.20$ \\
\hline $2007-08$ & $5,019.60$ & 133.2 & $5,152.80$ & 19.3 & 20.8 & $5,193.00$ \\
\hline $\begin{array}{l}\text { 2008-09 } \\
\text { (July- } \\
\text { February) }\end{array}$ & $2,794.40$ & - & $2,794.40$ & -367.00 & -535.30 & $1,892.10$ \\
\hline Total & $17,558.20$ & $2,805.20$ & $20,363.80$ & $1,960.30$ & $1,619.80$ & $23,944.30$ \\
\hline
\end{tabular}

Source: Board of Investment

Country wise FDI inflows (Million \$)

\begin{tabular}{|l|c|c|c|c|c|c|c|c|}
\hline \multicolumn{1}{|c|}{ Country } & $2000-01$ & $2001-02$ & $2002-03$ & $2003-04$ & $2004-05$ & $2005-06$ & $2006-07$ & $2007-08$ \\
\hline USA & 92.7 & 326.4 & 211.5 & 238.4 & 325.9 & 516.7 & 913.1 & $1,309.3$ \\
\hline UK & 90.5 & 30.3 & 219.4 & 64.6 & 181.5 & 244.0 & 860.1 & 460.2 \\
\hline U.A.E & 5.2 & 21.5 & 119.7 & 134.6 & 367.5 & $1,424.5$ & 661.5 & 588.6 \\
\hline Japan & 9.1 & 6.4 & 14.1 & 15.1 & 45.2 & 57.0 & 64.4 & 131.2 \\
\hline Hong Kong & 3.6 & 2.8 & 5.6 & 6.3 & 32.3 & 24.0 & 32.6 & 339.8 \\
\hline Switzerland & 3.6 & 7.4 & 3.1 & 205.3 & 137.5 & 170.6 & 174.7 & 169.3 \\
\hline Saudi Arabia & 56.6 & 1.3 & 43.5 & 7.2 & 18.4 & 277.8 & 103.5 & 46.2 \\
\hline Germany & 15.5 & 11.2 & 3.7 & 7.0 & 13.1 & 28.6 & 78.9 & 69.6 \\
\hline Korea(South) & 3.7 & 0.4 & 0.2 & 1.0 & 1.4 & 1.6 & 1.5 & 1.2 \\
\hline Norway & 0.0 & 0.1 & 0.3 & 146.6 & 31.4 & 252.6 & 25.1 & 275.0 \\
\hline China & 0.0 & 0.3 & 3.0 & 14.3 & 0.4 & 1.7 & 712.0 & 13.7 \\
\hline Others & 41.9 & 76.6 & 173.9 & 108.6 & 369.3 & 521.9 & $1,512.2$ & $1,748.7$ \\
\hline Total & 322.4 & $\mathbf{4 8 4 . 7}$ & $\mathbf{7 9 8 . 0}$ & $\mathbf{9 4 9 . 0}$ & $\mathbf{1 5 2 3 . 9}$ & $\mathbf{3 5 2 1 . 0}$ & $\mathbf{5 1 3 9 . 6}$ & $\mathbf{5 , 1 5 2 . 8}$ \\
\hline Privatization & - & 127.4 & 176.0 & 198.8 & 363.0 & 1540.3 & 266.4 & 133.2 \\
\hline Proceeds & 322.4 & $\mathbf{3 5 7 . 3}$ & $\mathbf{6 2 2 . 0}$ & $\mathbf{7 5 0 . 2}$ & $\mathbf{1 , 1 6 0 . 9}$ & $\mathbf{1 , 9 8 0 . 7}$ & $\mathbf{4 , 8 7 3 . 2}$ & $\mathbf{5 , 0 1 9 . 6}$ \\
\hline FDI Excluding Pvt. & & & & & & & & \\
\hline Proceeds & & & & & & & & \\
\hline
\end{tabular}

Source: State Bank of Pakistan 
Sector-wise FDI in Pakistan

\begin{tabular}{|c|c|c|c|c|c|c|c|c|}
\hline Sector & $\begin{array}{c}2000- \\
01\end{array}$ & $\begin{array}{c}2001- \\
02\end{array}$ & $\begin{array}{c}2002- \\
03\end{array}$ & $\begin{array}{c}2003- \\
04\end{array}$ & $\begin{array}{c}2004- \\
05\end{array}$ & $\begin{array}{c}2005- \\
06\end{array}$ & $\begin{array}{c}2006- \\
07\end{array}$ & $\begin{array}{c}2007- \\
08\end{array}$ \\
\hline Oil \& Gas & 80.7 & 268.2 & 186.8 & 202.4 & 193.8 & 312.7 & 545.1 & 634.8 \\
\hline Financial Business & (34.9) & 3.6 & 207.4 & 242.1 & 269.4 & 329.2 & 930.3 & $1,607.6$ \\
\hline Textiles & 4.6 & 18.5 & 26.1 & 35.4 & 39.3 & 47.0 & 59.4 & 30.1 \\
\hline Trade & 13.2 & 34.2 & 39.1 & 35.6 & 52.1 & 118.0 & 172.1 & 175.5 \\
\hline Construction & 12.5 & 12.8 & 17.6 & 32.0 & 42.7 & 89.5 & 157.1 & 88.5 \\
\hline Power & 39.9 & 36.4 & 32.8 & (14.2) & 73.4 & 320.6 & 193.4 & 70.3 \\
\hline Chemical & 20.3 & 10.6 & 86.1 & 15.3 & 51.0 & 62.9 & 46.1 & 78.0 \\
\hline Transport & 45.2 & 21.4 & 87.4 & 8.8 & 10.6 & 18.4 & 30.2 & 73.0 \\
\hline $\begin{array}{l}\text { Communication } \\
\text { (IT\&Telecom) }\end{array}$ & NA & 12.8 & 24.3 & 221.9 & 517.6 & $1,937.7$ & $1,898.7$ & $1,625.3$ \\
\hline Others & 140.9 & 66.2 & 90.4 & 170.1 & 274.0 & 285.0 & $1,107.2$ & 769.7 \\
\hline Total & 322.4 & 484.7 & 798.0 & 949.4 & $1,523.9$ & $3,521.0$ & $5,139.6$ & $5,152.8$ \\
\hline $\begin{array}{l}\text { Privatisation } \\
\text { Proceeds }\end{array}$ & - & 127.4 & 176.0 & 198.8 & 363.0 & $1,540.3$ & 266.4 & 133.2 \\
\hline $\begin{array}{l}\text { FDI Excluding Pvt. } \\
\text { Proceeds }\end{array}$ & 322.4 & 357.3 & 622.0 & 750.6 & 1160.9 & 1980.7 & 4873.2 & $5,019.6$ \\
\hline
\end{tabular}

Source: State Bank of Pakistan

Pakistan received 5 billion US\$ in the year 2007 which were recorded the highest, Now Pakistan is facing a declining trend due to current economic crunch across the globe. Under the current situation, there is a need that economist should take considerable measures for pushing the foreign investment retain in the country. According to a large number of analysts, no foreign company, which entered Pakistan, has ever left the country. Rather they have been expanding their operations through expansion and diversification. Additionally, even at the time of nationalization, all the foreign investment was exempted from the preview of nationalization. However, in many countries foreign investment has been the first to be nationalized. 
Sectors Receiving FDI in Pakistan

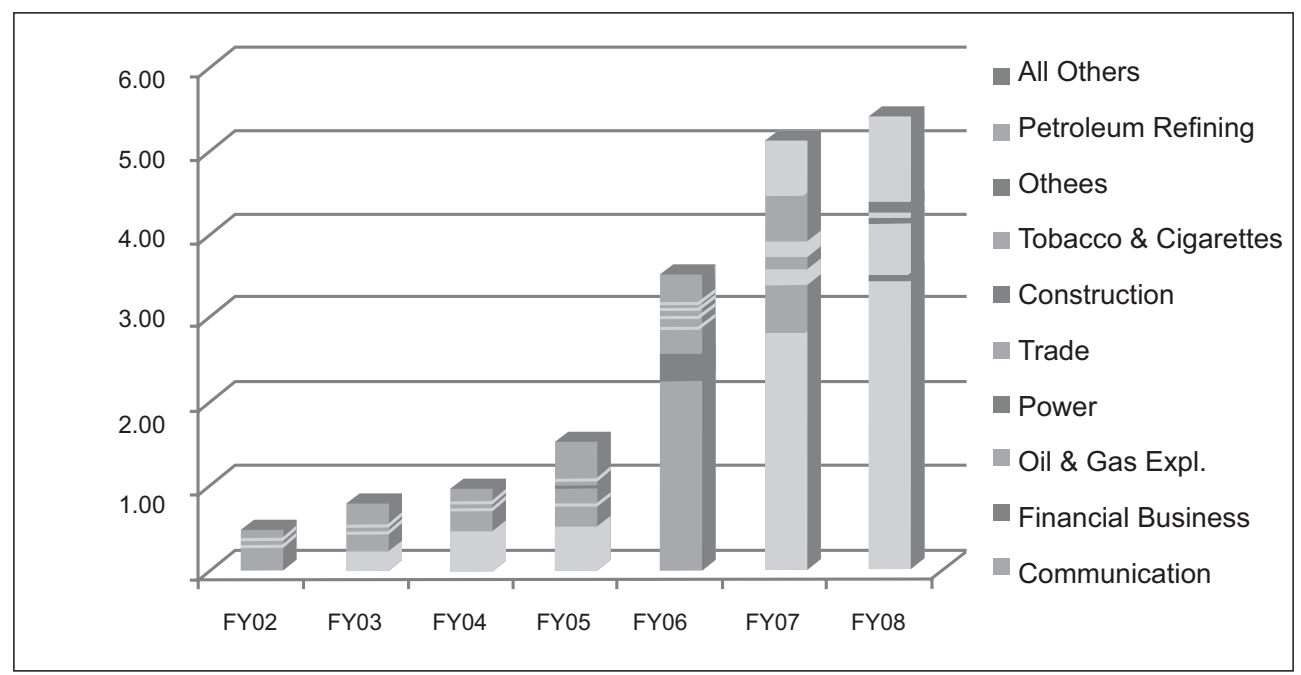

Source: State Bank of Pakistan

\section{Policy Recommendations}

Pakistan should make strong efforts to attract as much FDI as possible to the foreign exchange sectors in the short-term. Taking into account unfavorable balance of payments prospects, it should renounce from attracting any further massive FDI in the non-foreignexchange-earning sectors for some years in the future. Political stability and satisfactory law and order situation are likewise critical to attract FDI.

\section{Empirical Analysis}

\subsection{Description of Data Sources}

Annual data from Fiscal year 1975 to 2008 were collected from annual publications such as Statistical Annexure SBP Annual Report, Handbook of Statistics on Pakistan Economy 2005, Monthly Statistical Bulletin compiled by Statistics \& DWH Department State Bank of Pakistan and Year Book by Federal Bureau of Statistics. Openness is measured as ratio of total external trade export and import with gross domestic product.

\subsection{FDI and Determinants Results}

FDI and all regressors were tested for stationary using Augmented Ducky-Fuller test in E-Views to fulfill the prerequisite condition of unit roots. Log-transformation and differencing were used to obtain stationary series. 


\begin{tabular}{|l|l|r|}
\hline Variable & Transformation & t-statistic \\
\hline FDI & $\Delta \log _{\mathrm{e}}$ FDI & $-7.43(0.00)$ \\
\hline Openness & $\Delta \log _{\mathrm{e}}$ Openness & $-6.41(0.00)$ \\
\hline Exchange Rate & $\Delta \log _{\mathrm{e}}$ X Rate & $-3.78(0.01)$ \\
\hline Interest Rate & $\Delta \log _{\mathrm{e}}$ I Rate & $-4.68(0.00)$ \\
\hline Inflation & $\Delta \log _{\mathrm{e}}$ Inflation & $-2.65(0.01)$ \\
\hline
\end{tabular}

\subsection{Estimated Model}

\begin{tabular}{|l|r|r|r|r|}
\hline Dependent Variable & Coefficient & Standard Error & \multicolumn{1}{c|}{ t } & p-value \\
\hline$\Delta$ Log $_{\mathrm{e}}$ Openness & 2.87 & 0.54 & 5.35 & 0.00 \\
\hline$\Delta$ Log $_{\mathrm{e}}$ INFLATION & 0.46 & 0.14 & 3.27 & 0.00 \\
\hline$\Delta$ Log $_{\mathrm{e}}$ XRATE & 1.47 & 0.60 & 2.44 & 0.02 \\
\hline No of observations & 0.42 & 0.12 & 3.44 & 0.00 \\
\hline $\mathrm{AR}(4)$ & -0.92 & 0.03 & -36.20 & 0.00 \\
\hline MA(5) Squared & 2.87 & 0.54 & 5.35 & 0.00 \\
\hline Sum & 2.06 & & & \\
\hline R-square & 0.68 & & & \\
\hline Akaike info criterion & 0.29 & & & \\
\hline
\end{tabular}

The estimated model indicates positive relation between economy openness to the rest of the world with the FDI flows in the economy consistent with the theoretical low coefficient of exchange rate is and coefficients shows the consistency in exchange rates and overall price market remains a determinant of FDI in recent years. Estimated model is fit for all the necessary diagnostics applied to white noise residuals of fitted model.

\subsection{Diagnostic Checking of Model}

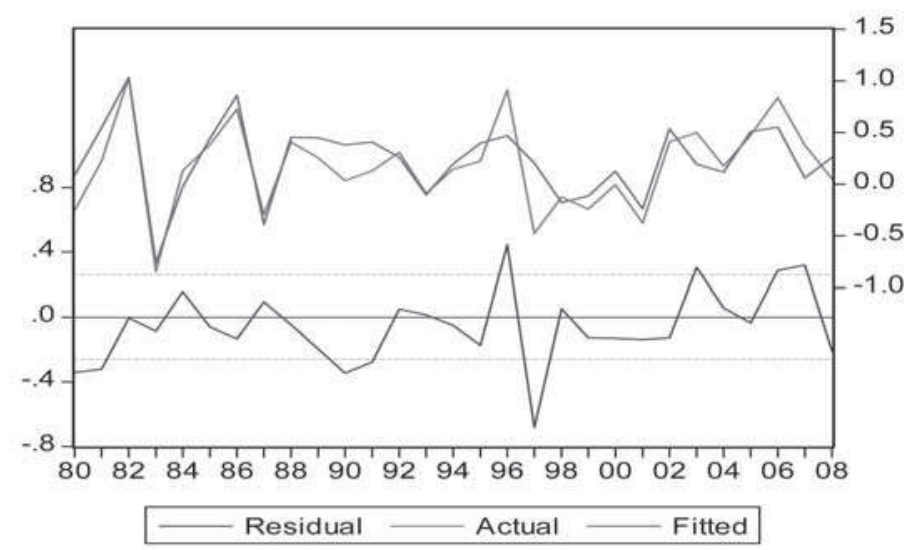




\section{Correlogram of Residuals}

Date: 04/01/09 Time: 12:55

Sample: 19802008

Included observations: 29

Q-statistic probabilities adjusted for 2 ARMA term(s)

\begin{tabular}{c|c|c|c|ccc}
\hline \hline \multicolumn{2}{c}{ Autocorrelation Partial Correlation AC PAC Q-Stat Prob } \\
\hline \hline
\end{tabular}

\section{Correlogram of Residuals Square}

Date: 04/01/09 Time: 13:14

Sample: 19802008

Included observations: 29

Q-statistic probabilities adjusted for 2 ARMA term(s)

\begin{tabular}{c}
\hline \hline \multicolumn{1}{c}{ Autocorrelation Partial Correlation AC PAC Q-Stat Prob } \\
\hline \hline
\end{tabular}

Histogram Normality Test

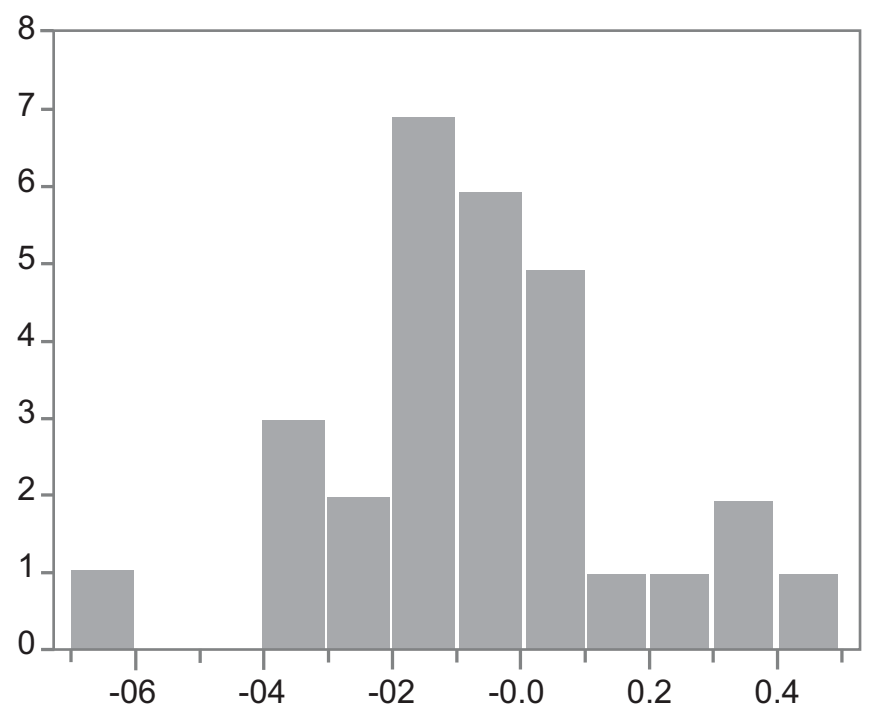

Series: Residuals

Sample 19802008

Observations 29

Mean

$-0.058384$

Median

$-0.059026$

Maximum

0.444655

Minimum

$-0.682260$

Std. Dev.

0.232642

Skewness

$-0.109293$

Kurtosis

3.694235

Jarque-Bera

0.640106

Probability

0.726111 
Breusch-Godfrey Serial Correlation LM Test:

\begin{tabular}{|c|c|c|c|}
\hline F-statistic & 0.229792 & Probability & 0.636205 \\
\hline Obs*R-squared & 0.000000 & Probability & 1.000000 \\
\hline
\end{tabular}

Test Equation:

Dependent Variable: RESID

Method: Least Squares

Date: 04/01/09 Time: 13:45

Presample missing value lagged residuals set to zero.

\begin{tabular}{cclcc}
\hline \hline Variable & Coefficient & Std. Error & t-Statistic & Prob. \\
\hline \hline D(LINFLATION) & 0.026782 & 0.152491 & 0.175632 & 0.8621 \\
D(LOPEN) & 0.095865 & 0.580555 & 0.580555 & 0.8703 \\
D(LXRATE) & 0.109770 & 0.655232 & 0.167529 & 0.8684 \\
AR(4) & -0.002222 & 0.124358 & -0.017867 & 0.9859 \\
MA(5) & 0.002662 & 0.026514 & 0.100403 & 0.9209 \\
RESID(-1) & 0.121117 & 0.252661 & -0.479366 & 0.6362 \\
\hline \hline R-squared & -0.054694 & Mean dependent var & -0.058384 \\
Adjusted R-squared & -0.283975 & S.D. dependent var & 0.232642 \\
S.E. of regression & 0.263613 & Akaike info criterion & 0.353320 \\
Sum squared resid & 1.598307 & Schwarz criterion & 0.636208 \\
Log likelihood & 0.876866 & Durbin-Watson stat & 1.895884
\end{tabular}

Heteroskedasticity Test: (No Cross Terms):

White Heteroskedasticity Test:

\begin{tabular}{llll}
\hline \hline F-statistic & 1.264834 & Probability & 0.313373 \\
Obs ${ }^{*}$ R-squared & 7.437935 & Probability & 0.282237 \\
\hline \hline
\end{tabular}

White Heteroskedasticity Test: ( Cross Terms):

White Heteroskedasticity Test:

\begin{tabular}{llll}
\hline \hline F-statistic & 0.884588 & Probability & 0.555620 \\
Obs*R-squared & 8.563294 & Probability & 0.478521
\end{tabular}

Journal of Independent Studies and Research - MSSE

Volume 9 Number 2

July 2011 76 


\subsection{Limitation of Empirical Analysis}

The analysis is based on data collected from the years 1975 - 2008. In fact the size of available data is very small and it is not enough to produce reliable results. But due to lack of data availability we are restricted. Our results are reliable under these limitations. But for better and comprehensive results to understand the effect of institutional fitness on FDI we need large sample size.

\section{Conclusion and Recommendations}

Pakistan is located at the heart of Asia, has a 1,046 kilometer coastline along the Arabian Sea and can serve as the gateway of trade to Central Asian, Gulf and European Markets. It has strategic advantage of being surrounded by Afghanistan and Iran in the west, the India in the east and China in the far northeast. Pakistan is the sixth most populous city in the world thus a big market for seller and cheap and highly sophisticated trained labor market.

Pakistan has well developed financial system, stock exchanges and foreign exchange market with an efficient regulatory framework to safe the interest of foreign and domestic investor. Because of its geo-political environment, rich natural resources, and a big market for seller and produce it has much potential to attract more foreign investment and trade from the world; policy makers should consider the factors that attract the multinational organizations to bring more investment in the economy and channelizing the investment in production sector to increase the turnover and employment. Inflow of investment in agriculture and textile sectors will increase the efficiency of these sectors and will resolve the food crises and employment issues in the economy. To explore further determinants of Foreign Investment, a cross country analysis of developing economies can be recommended. 


\section{References}

Asiedu, et al. (2002),"Ownership Structure in Foreign Direct Investment Projects", Review of Economics and Statistics.

Aslam (1987) "The Impact of Foreign Capital Inflow on Savings and Investment: The Case of Pakistan". Pakistan Development Review Islamabad: Pakistan Institute of Development Economics.

Chenery, et al. (1966) "Foreign Assistance and Economic Development" American Economic Review.

Dunning, et al. (1993) Multinational Enterprises and the Global Economy, Harrow: Addison-Wesley.

Gastanaga, et al. (1998) "Host Country Reforms and FDI Inflows: How Much Difference Do They Make?" World Development.

Griffin, et al. (1970) "Foreign Capital, Domestic Savings and Development" Bulletin of Oxford University, Institute of Economics and Statistics. Oxford University Press.

Khan, et al (1993). "Foreign Aid, Domestic Savings and Economic Growth". Pakistan Development Review.

Leff, et al. (1969) "Dependency Rates and Saving Rates", American Economic Review, New York: American Economic Association.

Meyer K. E. (2003), "FDI spillovers in emerging markets: A literature review and new perspectives", mimeo, Copenhagen Business School.

Muhammad Arshad Khan (2007) "Foreign Direct Investment and Economic Growth: The Role of Domestic Financial Sector" PIDE Working Papers.

Shabbir, et al. (1992) "The Effects of Foreign Private Investment on Economic Growth in Pakistan", Pakistan Development Review, Islamabad: Pakistan Institute of Development Economics.

UNCTAD Catalogue Trade and Development Report (1997), "Globalization, Distribution and Growth". 